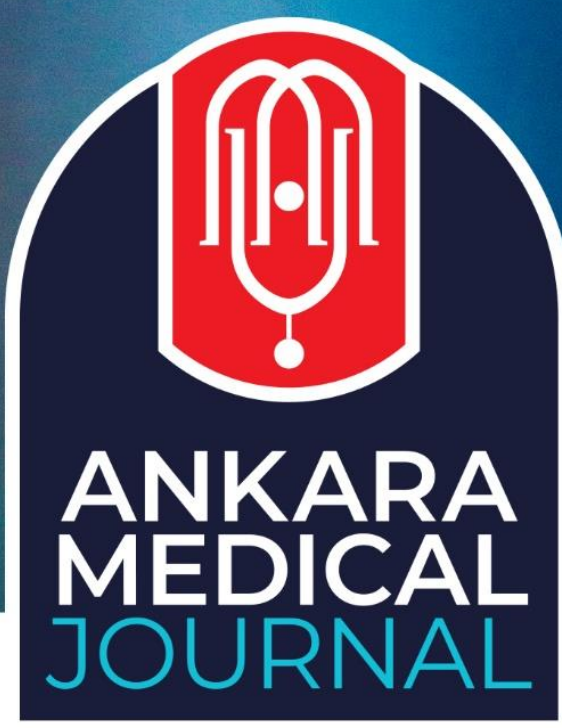

Research Article

Ankara Med J, 2020;(4):1088-1093 // (10) 10.5505/amj.2020.43815

\title{
ARTERIOVENOUS MALFORMATION OBSERVED IN THE AURICULA IN AN ELDERLY PATIENT: A CASE REPORT
}

\section{YAŞLI HASTADA AURİKULADA GÖRÜLEN ARTERIYOVENÖZ MALFORMASYON: OLGU SUNUMU}

\section{Sirin Kucuk ${ }^{1}$, (i) Izzet Goker Kucuk ${ }^{2}$}

${ }_{1}^{1}$ Department of Pathology, Faculty of Medicine, Uşak University, Uşak

${ }^{2}$ Spec. Dr. Kemal Öz Family Health Center, Uşak

Yazışma Adresi / Correspondence:

Dr. Öğr. Üyesi Sırın Kucuk (e-mail: ata2012irin53@yahoo.com)

Geliş Tarihi (Submitted): 11.04.2020 // Kabul Tarihi (Accepted): 05.10.2020

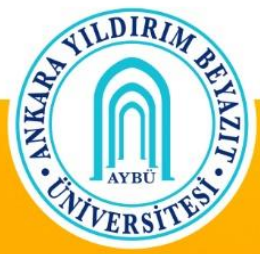

Ankara YIldırım Beyazıt University Faculty of Medicine 


\title{
Öz
}

Arteriyovenöz malformasyon (AVM); arter ile ven arasında kapiller bağlantı olmaksızın birbiriyle doğrudan iliş̧ili olduğu sıklıkla intrakraniyal yerleşimli anormal damarsal oluşumlardır. Lezyon baş boyun bölgesinde sık görülmesine rağmen özellikle aurikulada nadir görülür. Aile sağlığı merkezine kulak kepçesinde kanamalı kitle ve tinnitus şikayeti ile başvuran 64 yaşındaki erkek hasta bu șikayetleri üzerine kulak burun boğaz bölümüne yönlendirildi. Burada kitle eksizyonu yapıldı ve primer sütürle kapatıldı. Patoloji bölümümüze polipoid görünümde $1,7 \times 0,7 \times 0,7 \mathrm{~cm}$ boyutlarında ince bir sapı bulunan kesit yüzeyi kirli beyaz renkli, kanamalı bir materyal geldi. Histopatolojik incelemede düzgün sınırlı, kalın duvarlı, çeșitli büyüklüklerde ve çaplarda arter ve ven yapılarından olușan bir lezyon izlendi. Olguya yapılan immünhistokimyasal boyamalarda CD31 ve CD34 (+) Podoplanin (-) tespit edildi. Histokimyasal boyamada damar duvarlarında MTK (Masson's Trichrome boyaması ) ile boyanma saptandı. Tüm bu bulgularla olguya aurikulaya sınırlı bir AVM tanısı konuldu. Olgu nadir görülmesi nedeniyle literatür tartışması eşliğinde sunuldu.

Anahtar Kelimeler: Arteriyovenöz malformasyon, kulak kepçesi, yaşlı hasta.

\begin{abstract}
Arteriovenous malformation (AVM) refers to abnormal venous formations, which are generally localized to the intracranial region and directly related to each other without a capillary connection between artery and vein. The lesion is frequently seen in the head-neck region but rarely in the auricula. A 64-year-old male patient, who applied to the family health center with the complaints of tinnitus and hemorrhagic mass in the auricula, was referred to the otolaryngology department. The mass was excised there and then closed using a primary suture. A hemorrhagic material with $1.7 \times 0.7 \times 0.7 \mathrm{~cm}$ dimensions and, having a thin stem and off-white colored surface, and polypoid appearance was brought to our pathology department. In the histopathological examination, a well-circumscribed lesion consisting of arteries and vessels having different sizes and radii and thick walls was observed. In immunohistochemical staining, the case was found to be CD31 and CD34 (+) and Podoplanin (-). In histochemical staining, the staining with MTK (Masson's Trichrome Stain) was observed in vessel walls. In all these findings, the diagnosis of AVM limited to auricula was made. Since this case is rarely seen, it is presented together with a literature discussion.
\end{abstract}

Keywords: Arteriovenous malformation, auricula, elderly patient. 


\section{Introduction}

Vascular anomalies are congenital vascular diseases including the soft tissues and organs. Although the real incidence of vascular anomalies is not exactly known, they generally influence children and young adults. ${ }^{1-10}$ The arteriovenous malformation (AVM) constitutes 1.5\% of extracranial hemangiomas and is generally seen at the head, neck, face, and limbs. ${ }^{2,3}$ One of the largest series of arteriovenous malformations of the head and neck is from Kohout et al. They report a $16 \%$ incidence of lesions involving the ear (7). The cases with loss of hearing, swallowing difficulties, and vision disorders accompanied by complications of ulcer and hemorrhage necessitate treatment. ${ }^{2}$ Careful analysis of clinical characteristics and evaluation of therapeutic options form the basis of the successful management of AVMs. ${ }^{3}$ Some of the therapeutic options are pharmacotherapy with oral propranolol, transcatheter embolization, and surgical intervention. ${ }^{1}$ The case is presented here with the literature on AVM limited to auricula.

\section{Case}

With the complaints of mass and tinnitus in the right auricula frequently causing hemorrhage, a 64-year-old patient applied to our family health center (FHC). There was no symptom in the history of the patient. The mass was been there since his childhood but it has gradually grown in recent years and caused frequent bleeding and pain. Its dimensions have also increased in recent years. The patient has applied to the FHC since he was afraid of cancer. In physical examination, a pulsatile mass with polypoid appearance, thin stem, and off-white color, approx. $2 \times 1 \times 1 \mathrm{~cm}$ dimensions, and having bleeding at some points on its surface was detected on the auricula. In the Carotid - vertebral artery doppler USG performed in our case, both CCA (Common carotid artery), ICA (Internal carotid artery), and ECA (External carotid artery) lumen calibrations and intraluminal echoes were found to be normal. The other examination findings were normal. No characteristic sign was detected in the full blood, biochemistry, and hormone tests. Based on these findings, the patient was referred to the otolaryngology department. The mass on the patient's ear was totally excised and then closed using a primary suture. The excised material was then sent to the pathology department. No hemorrhage or any complication was observed during the follow-up process. In the macroscopic examination, an off-white mass having a thin stem, polypoid appearance, and dimensions of $1.7 \times 0.7 \times 0.7 \mathrm{~cm}$ and having hemorrhage at several points on its surface was detected. In the microscopic examination, however, a well-circumscribed lesion with thick walls and consisting of arteries and venous structures at different sizes and diameters were observed (Figure 1). In histochemical staining, MTK was found to be (+) in ligament and muscular tissues (Figure 2). During the immunohistochemical staining in vein walls, CD31 and CD34 were positive (+) (Figure 3) but Podoplanin was found to be negative (-). In these findings, the case was diagnosed with arteriovenous hemangioma/arteriovenous malformation. The informed consent form was obtained from the patient. 


\section{(10) \\ ANKARA \\ MEDICAL \\ JOURNAL}

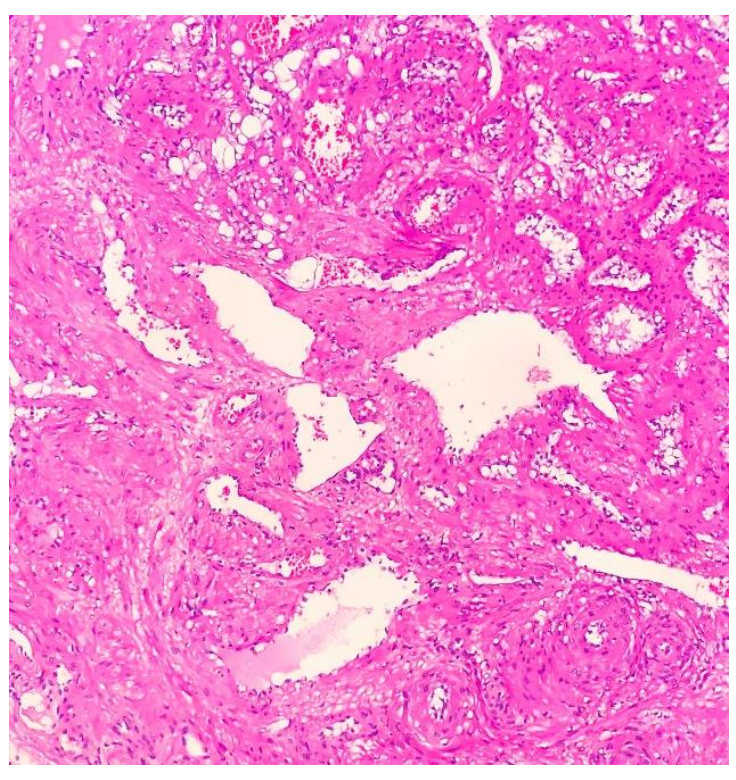

Figure 1. The well-circumscribed, thick-walled lesion consisting of arteries and veins of different sizes and diameters (HEx20)

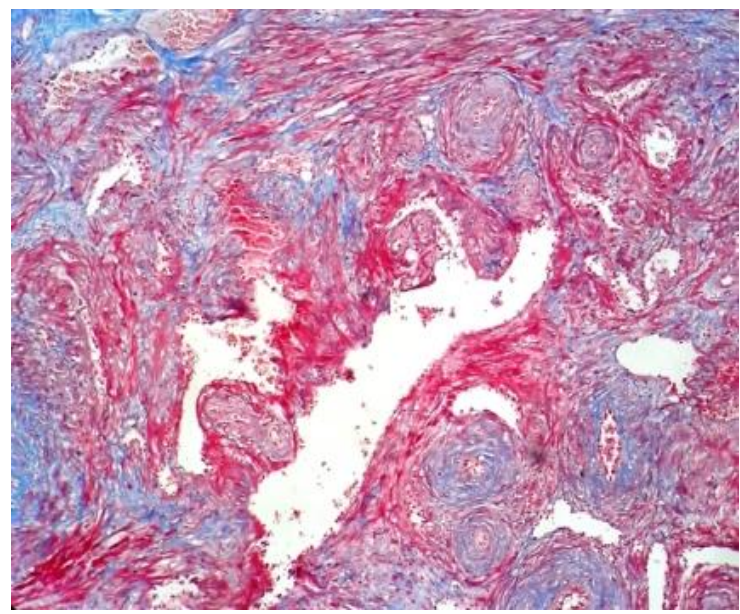

Figure 2. MTK histochemical staining on the vessel (MTKx20)

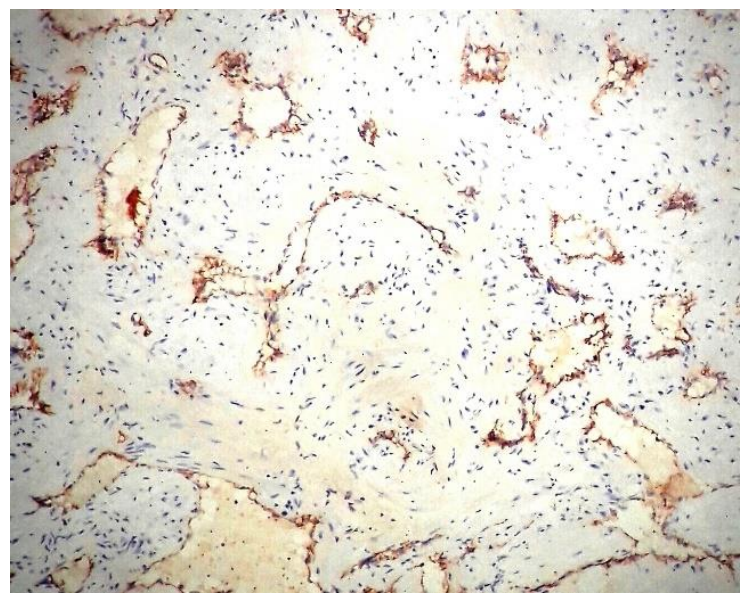

Figure 3. CD34 immunohistochemical staining on vessel wall positivity (CD34x20) 


\section{Discussion}

According to the classification made by Mulliken et al. in 1982, the vascular anomalies were classified as tumors and malformations. The biological classification was made using the physical findings, natural course, and cellular structures. 1,4

Although the pathogenesis of AVM is not clear, arteriovenous connections and local ischemia play a role in pathogenesis. ${ }^{4,5}$ Local ischemia plays an important role in the pathogenesis, especially for AVMs in the ear muscle. In angiographic studies carried out on auricular AVMs, loss of nutrition was observed in min. 2 of posterior auricular, superficial temporal, and occipital arteries among the main vessels feeding the posterior auricular. 4,5

Hemangiomas exhibit a multi-laminated basal membrane formation under the endothelium and endothelial hyperplasia in the phase of proliferation. From the clinical aspect, rapid growth was observed in the babyhood period. In the involution phase, histologic fibrosis and fat deposition are observed. From the clinical aspect, rapid growth is followed by the degradation period. The endothelium has different characteristics in hemangioma; Weibel-Palade particles, alkaline phosphatase, and factor VIII production are observed. ${ }^{1}$ It is more frequently seen among women. ${ }^{2}$ Infantile hemangiomas are the most frequently seen benign tumors among infants and $80 \%$ of them may degrade on their own without requiring therapy. Only the hemangiomas, applying pressure on the organs by enlarging and causing symptoms, such as those affecting the digestive tract and disturbing the hearing and vision require treatment. ${ }^{1}$

The arteriovenous malformations (AVM) are the result of embryologic and fetal development errors $\left(4^{\text {th }}-6^{\text {th }}\right.$ gestational weeks). Their pathogenesis hasn't been revealed yet. AVMs are generally detected at birth but they are generally misdiagnosed. In general, they are confused with capillary malformations (CM) and hemangiomas. ${ }^{4,6,7}$ The points of the body, where the vascular anomalies are observed most frequently, are the head and neck region (65\%), chest and trunk (25\%), and upper or lower extremities (10\%). ${ }^{1,4}$ There is no difference in terms of regression or gender. ${ }^{2}$ Rapid dimension increases may be seen due to trauma, puberty, pregnancy, and infections. AVMs have typically rapid flow. ${ }^{2,6-8}$ Although many AVMs are asymptomatic, severe pain, and/or hemorrhage may be seen in certain cases. The most common symptoms are pulse (51.2\%), bleeding (41.5\%) and pain (29.3\%). ${ }^{8}$ In the present case, the patient has applied to the family health center with complaints of tinnitus and mass causing frequent hemorrhage in the right auricula. 
The classification system used in classifying the AVMs was designed by Schobinger in the year 1990.2,6,8 According to the clinical classification by Schobinger, AVMs are divided into 4 (Table 1). According to Schobinger's classification, the present case was classified as Stage III. The clinical diagnosis is verified using ultrasonography and color Doppler imaging. The best result in grading the AVM is achieved by using the MR examination. AVM characteristically consists of feeding and draining veins. The angiography shows various arterial dilatation and curving, arteriovenous shunts, and dilated draining veins. Aneurysms may also be observed in aortas of elderly patients.6,8 but no aneurysm was found in the present case. From the histological aspect, AVMs are seen as reactive, hypertrophic, and thick-walled arteries and veins due to the increased blood flow. ${ }^{7}$ In the morphological examination of the present case, a well-circumscribed lesion consisting of thickwalled arteries and veins at different sizes and diameters was observed. In the immunohistochemical staining of vein structures, CD31 and CD34 were found to be positive (+) and Podoplanin to be negative (-). In the histochemical staining, MTK was found to be positive (+) in ligament and muscular tissue. In all these findings, the case was diagnosed with arteriovenous hemangioma/arteriovenous malformation.

In many cases, the treatment mainly consists of selective embolization, sclerotherapy, surgical resection, and reconstruction.6,8 No ligation or proximal embolization should be applied to the feeding vessels. This causes the immediate formation of new and fast-flow veins and nourishment of the nidus. If it is not possible to completely remove the nidus or for the young patients, for whom the wound causes severe deformation, embolization and sclerotherapy can be used in taking the symptoms such as pain, hemorrhage, or congestive heart failure under control. Embolization typically yields a temporary improvement because nidus continues being fed by the development of new veins. In surgery, a large excision including the nidus and the skin tissue around it should be performed. ${ }^{6,8}$ In the present case, total resection was applied to the nidus and surrounding tissue. No hemorrhage or any complication was observed during the follow-up.

In conclusion, auricular AVM is a very rarely seen lesion. In general, these lesions are diagnosed and treated at younger ages. The present case, however, is an attention-grabbing AVM since it was diagnosed at an elderly age and is limited to the auricula.

Table 1. Schobinger's classification for the AVMs.

\begin{tabular}{|l|l|}
\hline Stages & Characteristics \\
\hline Stage I (Silent) & $\begin{array}{l}\text { Pink-bluish skin, temperature, and arteriovenous } \\
\text { shunt in Doppler }\end{array}$ \\
\hline Stage II (Enlargement) & $\begin{array}{l}\text { Enlargement, bruit, pulsation, thrill, and } \\
\text { sensitive/curved veins }\end{array}$ \\
\hline Stage III (Destruction) & $\begin{array}{l}\text { Dystrophic skin changes, ulceration, (destruction), } \\
\text { skin necrosis, continuous pain, hemorrhage }\end{array}$ \\
\hline Stage IV (Decompensation) & Heart failure \\
\hline
\end{tabular}




\section{References}

1. Mulliken JB, Glowacki J. Hemangiomas and vascular malformations in infants and children: a classification based on endothelial characteristics. Plast Reconstr Surg. 1982;69(3):412-22.

2. Ulusan M, Kumral T.L, Aydın S, Oktay M. F. Aurikulanın arterio-venöz malformasyonu: Olgu sunumu. Dicle Tıp Dergisi. 2009; 37(1): 60-3.

3. Sofiane N, Ardhaoui H, Halily S et al. Arterio-Venous Vascular Malformation of the Auricle Supplied by the Collaterals of Six Main Arteries: Case Report. Journal of Otolaryngology Studies. 2018;1:1;1-3.

4. Gupta A, Gupta S, Kumar A. Bhattacharaya S, Jha M, Tiwari V. High-Flow Vascular Malformation of Ear: A Case Report. World J Plast Surg. 2018;7(2):256-60.

5. Woo H.J, Song S.Y, Kim Y.D, Bai C.H. Arteriovenous malformation of the external ear: a case report. Auris Nasus Larynx. 2008;35(4):556-8.

6. Wu J.K, Bisdorff A, Gelbert F, Enjolras O, Burrows P.E, Mulliken J.B. Auricular arteriovenous malformation: evaluation, management, and outcome. Plast Reconstr Surg. 2005;115(4):985-95.

7. Whitty LA, Murray JD, Null WE, Elwood ET, Jones GE. An arteriovenous malformation of the external ear in the pediatric population: A case report and review of the literatüre. Can J Plast Surg. 2009;17(4): 45-7.

8. Yolmo D, Madana J, Saxena S.K, Gopalakrishnan S. Long standing malformation of right sided pinna in an elderly man. Congenit Anom (Kyoto). 2010;50(1):68-70.

9. Kim S.H, Han S.H, Song Y, Park CS, Song JJ. Arteriovenous malformation of the external ear: a clinical assessment with a scoping review of the literature. Braz J Otorhinolaryngol. 2017;83(6):683-90.

10. Sadicka M, Wohlgemuthb W.A, Huelsec R, Lange B, Henzler T, Schoenberg SO, Sadick H. Interdisciplinary Management of Head and Neck Vascular Anomalies:Clinical Presentation, Diagnostic Findings and Minimalinvasive Therapies. Eur J Radiol Open. 2017;4: 63-8. 